\title{
Report of a joint DMRQC/Organon field trial to detect hepatitis A IgM by ELISA
}

\author{
E MARGARET SUPRAN*, J CRASKE $\ddagger$, RJC HART§, JB KURTZ\|, JV PARRY†, SUSAN J \\ SKIDMOREI, PS GARDNER*
}

From the *Division of Microbiological Reagents and Quality Control, the †Virus Reference Laboratory, 175 Colindale Avenue, London NW9, the $\ddagger$ Public Health Laboratory (PHL), Withington Hospital, Manchester, the §PHL, Church Lane, Heavitree, Exeter, the $\| P H L$, John Radcliffe Hospital, Oxford and the $\{$ Regional Virus Laboratory, East Birmingham Hospital.

SUMMARY The results of a field trial of a joint DMRQC/Organon ELISA kit for the detection of hepatitis A IgM antibody are reported. The participating laboratories were asked to use the kit to test a panel of 360 specimens consisting of duplicate coded samples of 180 sera. The panel was also tested by MACRIA in the Virus Reference Laboratory, Colindale. The ELISA was shown to be specific and sensitive giving good discrimination between acute and late convalescent hepatitis A sera. It was proposed that the same cut-off control as is used in the RIA (equivalent to 10 RIA units) should be adopted for the ELISA also.

The ability to detect specific IgM class antibodies is of great diagnostic value in clinical virology especially when the pathogen concerned is difficult to isolate and culture. The virus of hepatitis A (HAV) is one such pathogen. Only recently have workers been able to cultivate the virus in vitro ${ }^{1-3}$ although work began on the development of serological tests to detect anti-HAV once the virus had been identified by immune electron microscopy (IEM) in the stools of volunteers inoculated with the MS 1 strain of hepatitis A. ${ }^{4}$ Marmosets had already been shown to be susceptible to hepatitis $A^{56}$ and using an HAV antigen derived from the livers of experimentally infected animals, a complement fixation test, ${ }^{7}$ and an immune adherence haemagglutination test $^{8}$ were described. Purcell and coworkers ${ }^{9}$ developed a solid phase radioimmunoassay (RIA) for hepatitis A antigen and antibody, and later in 1978 several groups described an ELISA for the detection of anti-HAV and HAV-specific IgM. Amongst these Duermeyer and colleagues ${ }^{10}$ were the first workers to use the anti- $\mu$ capture technique. This technique, which was also employed in RIA, ${ }^{11}$ enables IgM antibodies from the specimen to be selectively bound onto the solid phase. This has the advantage that there is no competition for sites which occurs in the indirect solid phase immunoassay. IgM class antibody to HAV can be detected in the blood of patients with hepatitis type A usually at the onset of jaundice. The level of these antibodies

Accepted for publication 8 June 1983 reaches a peak approximately two weeks later, then declines gradually becoming barely detectable 60-80 days after onset. ${ }^{12}$ Thus HAV-specific IgM persists at appreciable levels for only a limited period enabling a diagnosis of acute HAV infection to be made on a single specimen of serum taken during that period.

An ELISA kit employing the anti- $\mu$ technique was developed commercially by Organon Tecknika and became available in the UK in 1982. As the Division of Microbiological Reagents and Quality Control (DMRQC), Colindale, is in the process of assessing the most suitable diagnostic reagents for hepatitis A for issue to PHLS laboratories, it was decided to investigate the Organon Tecknika kit. For reasons of economy and because it appeared to enhance the colour development, DMRQC decided to substitute their own anti- $\mu$ coated solid phase (Sheep antiserum to human $\mu$ chain, diluted $1 / 1000$, Seward Laboratory) into the kit, and with the agreement of Organon, a field trial of this hybrid DMRQC-Organon ELISA kit was conducted within the PHLS during the summer of 1982.

\section{Design of the trial}

Four PHLS laboratories (three Regional and one Area laboratory) three of which were already using RIA for the detection of anti-HAV IgM (MACRIA), were invited to collaborate. To assist us in the collection of samples for the trial, those laboratories who were able to were asked to submit 40-50 specimens, positive and negative for $\mathrm{HAV}$-specific 
Table 1 Hepatitis A IgM ELISA field trial-summary of results, in agreement with RIA results, obtained by the collaborating laboratories

\begin{tabular}{|c|c|c|c|c|c|c|c|c|c|c|c|c|c|c|}
\hline \multirow{3}{*}{ Category } & \multirow{3}{*}{$\begin{array}{l}\text { RIA } \\
\text { units }\end{array}$} & \multirow{3}{*}{$\begin{array}{l}\text { No. of } \\
\text { speci- } \\
\text { mens }\end{array}$} & \multicolumn{6}{|c|}{$\begin{array}{l}\text { ELISA results in agreement with } R I A \\
\text { specimens } 1-180\end{array}$} & \multicolumn{6}{|c|}{$\begin{array}{l}\text { ELISA results in agreement with RIA } \\
\text { Duplicate specimens } 181-360\end{array}$} \\
\hline & & & \multirow{2}{*}{$\begin{array}{l}\text { Unmodified } \\
\text { Organon } \\
\text { test }\end{array}$} & \multicolumn{5}{|c|}{$D M R Q C$-Organon hybrid test } & \multicolumn{6}{|c|}{$\begin{array}{l}\text { Unmodified DMRQC-Organon hybrid test } \\
\text { Organon } \\
\text { test }\end{array}$} \\
\hline & & & & $D M R Q C$ & C Lab 1 & Lab 2 & Lab 3 & Lab 4 & $D M R Q C$ & $D M R Q C$ & Lab1 & Lab 2 & $L a b 3$ & $3 L a b 4$ \\
\hline $\begin{array}{l}\text { Strongly } \\
\text { positive }\end{array}$ & $>50$ & 79 & 79 & 79 & $\begin{array}{l}76 \\
(3 N T)\end{array}$ & 79 & ${ }^{77}(1 \mathrm{NT})$ & $\begin{array}{l}78 \\
(1 \mathrm{NT})\end{array}$ & 79 & 79 & $\begin{array}{l}75 \\
(3 N T)\end{array}$ & $\begin{array}{l}77 \\
(1 \mathrm{NT})\end{array}$ & 79 & 77 \\
\hline $\begin{array}{l}\text { Moderately } \\
\text { strong } \\
\text { positive }\end{array}$ & y10-50 & 7 & 7 & 7 & 7 & 7 & $\stackrel{6}{(1 \mathrm{NT})}$ & 6 & 7 & 7 & $\stackrel{6}{(1 N T)}$ & 7 & 7 & 7 \\
\hline $\begin{array}{l}\text { Weakly } \\
\text { positive }\end{array}$ & $5-10$ & 8 & 4 & 8 & $\stackrel{4}{(1 N T)}$ & 6 & 4 & $\stackrel{4}{4}(1 \mathrm{NT})$ & 3 & 5 & 6 & 7 & 2 & 3 \\
\hline $\begin{array}{l}\text { Equivocal } \\
\text { Negatives }\end{array}$ & $\begin{array}{l}1-5 \\
<1\end{array}$ & $\begin{array}{r}6 \\
80\end{array}$ & $\begin{array}{r}1 \\
80\end{array}$ & $\begin{array}{r}1 \\
80\end{array}$ & $\begin{array}{l}4 \\
54 \\
(2 \mathrm{NT})\end{array}$ & $\begin{array}{r}1 \\
79\end{array}$ & $\begin{array}{r}0 \\
80\end{array}$ & $\begin{array}{l}1 \\
80\end{array}$ & $\begin{array}{r}2 \\
80\end{array}$ & $\begin{array}{r}1 \\
80\end{array}$ & $\begin{array}{l}1 \\
72 \\
(1 N T)\end{array}$ & $\begin{array}{r}0 \\
78\end{array}$ & $\begin{array}{r}1 \\
80\end{array}$ & $\begin{array}{r}0 \\
80\end{array}$ \\
\hline
\end{tabular}

NT = not tested-specimen had dried up in transit.

NB Remaining specimens were in disagreement with RIA (see Table 3).

IgM antibody. Some specimens were also received from the Virus Reference Laboratory (VRL), Colindale. These specimens included sera strongly positive for hepatitis A IgM, and sera weakly positive being taken three to six months after onset of symptoms. In addition there were convalescent hepatitis B sera, sera containing IgM antibodies to $\mathrm{HBcAg}$, and $\mathrm{HBsAg}$ carrier specimens; sera positive for EBV-specific IgM; sera positive for rheumatoid factor (RV) with and without anti-HAV IgG; and normal control sera.

The assembled panel comprised 360 sera, specimens 181-360 being duplicates of specimens 1-180 but randomly assorted. A set of the 360 specimens was issued to each participating laboratory together with the DMRQC-Organon ELISA kit. This consisted of four anti- $\mu$ coated Nunc Immunoplates (96 well, flat-bottomed polystyrene microELISA plates) and two positive and one negative control sera supplied by DMRQC. HAV antigen, anti-HAV conjugate, and substrate (OPD and urea peroxide) were supplied by Organon Tecknika. The laboratories were asked to test the specimens consecutively in four batches so that one coated plate (sufficient for 90 specimens and six controls) would be used on each occasion and duplicate specimens would therefore never be tested together on the same day (see appendix for the Test Procedure). The panel was also tested in DMRQC following the same procedure, and in addition the specimens were tested using unmodified Organon Tecknika ELISA kits, the manufacturer's instructions being followed precisely. All workers were asked to read the results by eye, any colour development in a well which was at all greater than that in the negative control wells to be scored as positive. If a spectrophotometer was available, extinctions at $492 \mathrm{~nm}$ were to be recorded. Finally, the panel was tested by MACRIA in the VRL when their own very sensitive $\mu$-antibody capture system was used, ${ }^{13}$ employing 8 tissue culture-derived HAV antigen. ${ }^{14}$ In this MACRIA, dilutions of a positive control pool of acute hepatitis A sera which had been ascribed an arbitrary 100 units, were included in each batch of tests in order that a standard curve could be constructed for the quantitation of test samples. Dilutions of this positive control pool were made in anti-HAV negative serum.

\section{Results}

On the basis of the MACRIA results, the 180 sera in the panel were divided into positive, negative, and equivocally positive for the presence of HAVspecific IgM. The positive group was further subdivided into strongly positive (>50 RIA units), moderately strongly positive (10-50 RIA units), and weakly positive (5-10 RIA units). Any specimen which had 1-5 RIA units was placed in the equivocal category. In VRL the equivocal category includes all specimens with from one to 10 units, definite positives having $>10$ units. However in this trial, all eight specimens with from 5-10 units were known convalescent hepatitis A sera, four being obtained at three months, one at four months, and three at six months post onset of symptoms. Therefore these specimens were described as "weakly positive". Of the positives ( $>5$ RIA units), $85 \%$ (79/94) were strongly positive ( $>50$ units) and of these $61 \%(48 / 79)$ contained over 100 units. 
Table 2 Percentage of ELISA results in agreement with RIA

\begin{tabular}{|c|c|c|c|c|c|c|c|c|c|c|c|c|c|}
\hline \multirow[b]{3}{*}{ Category } & \multirow[b]{3}{*}{ No } & \multicolumn{6}{|c|}{$\begin{array}{l}\text { Percentage ELISA results in agreement with RIA } \\
\text { specimens Nos } 1-180\end{array}$} & \multicolumn{6}{|c|}{$\begin{array}{l}\text { Percentage ELISA results in agreement with RIA } \\
\text { duplicate specimens Nos } 181-360\end{array}$} \\
\hline & & \multirow{2}{*}{$\begin{array}{l}\text { Organon } \\
\text { DMRQC }\end{array}$} & \multicolumn{5}{|c|}{$D M R Q C$-Organon hybrid test } & \multirow{2}{*}{$\begin{array}{l}\text { Organon } \\
\text { DMRQC }\end{array}$} & \multicolumn{5}{|c|}{$D M R Q C$-Organon hybrid test } \\
\hline & & & $D M R Q C$ & Lab 1 & Lab 2 & Lab 3 & $L a b 4$ & & $D M R Q C$ & Lab 1 & Lab 2 & Lab 3 & $L a b 4$ \\
\hline $\begin{array}{l}\text { Positive } \\
>5 \text { RIA units }\end{array}$ & 94 & 96 & 100 & 97 & 98 & 95 & 96 & 95 & 97 & 97 & 98 & 94 & 93 \\
\hline $\begin{array}{l}\text { Negative } \\
<\text { 1RIA unit }\end{array}$ & 80 & 100 & 100 & 69 & 99 & 100 & 100 & 100 & 100 & 91 & 98 & 100 & 100 \\
\hline
\end{tabular}

Table 3 Concordant and discrepant ELISA results obtained by each participating laboratory on duplicate specimens

\begin{tabular}{|c|c|c|c|c|c|c|c|c|c|}
\hline \multirow{3}{*}{$\begin{array}{l}\text { RIA } \\
\text { Category } \\
\text { (units) }\end{array}$} & \multirow{3}{*}{$\begin{array}{l}\text { No } \\
\text { of } \\
\text { specimens }\end{array}$} & \multirow{2}{*}{\multicolumn{2}{|c|}{$\begin{array}{l}\text { ELISA } \\
\text { results on } \\
\text { duplicate } \\
\text { specimens }\end{array}$}} & \multicolumn{6}{|l|}{$E L I S A$} \\
\hline & & & & \multirow{2}{*}{$\begin{array}{l}\begin{array}{l}\text { Organon } \\
\text { test }\end{array} \\
D M R Q C\end{array}$} & \multicolumn{5}{|c|}{$D M R Q C$-Organon hybrid test } \\
\hline & & $\begin{array}{l}\text { 1st } \\
\text { specimen }\end{array}$ & $\begin{array}{l}\text { 2nd } \\
\text { specimen }\end{array}$ & & $D M R Q C$ & Lab 1 & $L a b 2$ & Lab 3 & Lab 4 \\
\hline \multirow{6}{*}{$\begin{array}{l}\text { Strongly } \\
\text { positive } \\
(>50 \text { units }) \\
\text { Moderately } \\
\text { strongly } \\
\text { positive } \\
(10-50 \text { units) }\end{array}$} & \multirow[t]{3}{*}{79} & + & + & 79 & 79 & 78 & 78 & 78 & 77 \\
\hline & & - & - & - & - & - & - & - & - \\
\hline & & $+(-)$ & $-(+)$ & - & $\overline{-}$ & 1 & 1 & 1 & 2 \\
\hline & \multirow[t]{3}{*}{7} & +1 & + & 7 & 7 & 7 & 7 & 7 & 6 \\
\hline & & $\overline{+}(-)$ & & - & - & - & - & - & $\overline{1}$ \\
\hline & & $+(-)$ & & & & & & & \\
\hline \multirow{3}{*}{$\begin{array}{l}\text { Weakly } \\
\text { positive } \\
\text { (5-10 units) }\end{array}$} & \multirow[t]{3}{*}{8} & + & + & 2 & 5 & 3 & 5 & 2 & 3 \\
\hline & & - & - & 3 & - & - & - & 2 & 3 \\
\hline & & $+(-)$ & $-(+)$ & 3 & 3 & 5 & 3 & 4 & 2 \\
\hline \multirow{2}{*}{$\begin{array}{l}\text { Equivocal } \\
\text { (1-5 units) }\end{array}$} & \multirow[t]{3}{*}{6} & + & + & 1 & - & 1 & - & - & - \\
\hline & & - & - & 4 & 4 & 2 & 5 & 5 & 5 \\
\hline \multirow{3}{*}{$\begin{array}{l}\text { Negative } \\
(<1 \text { unit })\end{array}$} & & $\begin{array}{l}+(-) \\
+\end{array}$ & $\begin{array}{l}-(+) \\
+\end{array}$ & 1 & 2 & $\begin{array}{l}3 \\
2\end{array}$ & 1 & 1 & 1 \\
\hline & \multirow{2}{*}{80} & - & & $8 \overline{0}$ & 80 & 51 & 77 & 80 & 80 \\
\hline & & $+(-)$ & $-(+)$ & - & - & 27 & 3 & - & - \\
\hline
\end{tabular}

NB A few specimens were not tested due to insufficient specimen-these specimens were counted as having obtained the "right" answer that is, giving the same results as RIA.

Table 1 summarises the ELISA results obtained by the participating laboratories and compares the results on the first 180 specimens with those obtained on the randomly assorted duplicate specimens. These results are based on colour development as judged by eye. The results received from Lab 1 are clearly out of line compared with the others. This laboratory reported initial difficulties with the test, and as the controls were not satisfactory the results would have been regarded as invalid and not reported if this had been other than a field trial. The performances of the other participating laboratories were very good (Table 2). It is evident that the ELISA is not quite as sensitive as RIA for the detection of hepatitis A IgM as the specimens that went undetected were mainly in the weakly positive (5-10 RIA units) category. The unmodified Organon Tecknika kit performed as well as the joint DMRQC/Organon kit overall.

The agreement of results obtained within each laboratory between the two samples of each specimen can be seen in Table 3. Again excluding Lab 1, the agreements for positive specimens with 10 RIA units and for negative specimens were very good. With the weakly positive specimens (5-10 RIA units) there were more apparently discrepant results. Undoubtedly this was due to the difficulty of identifying very weak colour development. Among the six sera giving equivocal results by RIA were two follow-up specimens taken 12 months after onset, and two RF positive sera. All these (both first and duplicate samples) were negative by ELISA. In the remaining two sera, hepatitis A IgM was just detectable by ELISA in one of the samples, if not both, by at least two laboratories. The history of one of these sera was unknown, but the other was taken only 12 weeks after the onset of hepatitis $A$.

The specimens containing HBsAg, EBV- and $\mathrm{HBcAg}-$ specific IgM and anti-HAV IgG did not constitute a problem, all gave unequivocally negative results in both enzyme assays (Organon and the joint DMRQC/Organon assay) and in the VRL MACRIA. There were 10 sera which were known to be RF-positive. By RIA, eight gave negative results 
and two gave equivocal results having 2.3 and 1.4 units anti-HAV IgM respectively. Excluding the results from Lab 1, all 10 specimens and their duplicates were reported to be entirely negative for anti-HAV IgM by ELISA.

\section{Discussion}

This hepatitis A IgM ELISA was a new test to the collaborating laboratories and as insufficient reagents were available to allow for any repeat testing, the onus was upon laboratories not to make any mistakes. From their experience in handling the large numbers of specimens required for this trial, Lab 1 suggested that the $10 \mu$ l specimen dilution should be added to the wells before the $90 \mu$ l buffer and not vice versa as recommended in the test procedure (see Appendix, steps 1 and 2) because errors were less likely to be made if this order was adopted. Alternatively a dye may be added to the initial specimen dilutions and the original protocol adhered to. The kits from which the Organon reagents were taken were nearing their expiry date by the time the trial actually took place, and it was noted that the colour development was weaker than it had been several months earlier when the preliminary tests were carried out in DMRQC. This must have resulted in a decrease in the sensitivity of the assay. In the instructions accompanying the Organon kits it states that the positive control must give an extinction at $492 \mathrm{~nm}$ of above 0.45 and the negative control an extinction of less than 0.20 with the Organon Tecknika Microelisa reader blanked on air. A sample is then considered positive when the extinction is greater than $0 \cdot 20$. In DMRQC the positive controls in the joint DMRQC-Organon test achieved extinctions in the region of $0.40-0.45$ but with the unmodified Organon Tecknika assay, the positive extinctions were only in the region of 0.30 . The negative extinctions were correspondingly lower, being approximately 0.15 for the hybrid test and 0.10 for the unmodified Organon test. Three other laboratories used a spectrophotometer (Dynatech MR580 Microelisa reader, or Titertek Multiskan) to augment their readings by eye. These laboratories reported extinction readings similar to or slightly lower than those of DMRQC. We understand that Organon have now improved the stability of their kits and extinction values of greater than 0.50 are normally obtained for the positive control even when the kit has reached its expiry date.

A different problem was encountered by Lab 2, namely a high ambient temperature $\left(29-32^{\circ} \mathrm{C}\right)$ in the room where the tests were carried out. Specimens 181-360 were tested by them during a heat wave and in order to prevent high background col- our developing they found it was necessary to incubate the plates in a $20^{\circ} \mathrm{C}$ incubator at all stages of the test procedure which stipulated room temperature. Despite the problems relating to colour development outlined above it is clear from the results that workers were able to interpret the patterns correctly.

Several laboratories reported that a colour cut-off control at the lower limits of what is considered significantly positive would have been a desirable addition to the kit. During the early acute phase of illness (up to two-three months after onset) specimens of serum generally contain $>50$ RIA units of HAV-specific IgM. This level diminishes gradually over the succeeding months to between 5 and 10 units at six months. Very rarely however, 1-3 units may still be detectable two years after the illness (John Parry, VRL, personal communication 1983). For diagnostic purposes IgM should be detected as early as possible during the acute stage of illness but not for too long during the late convalescent stage. For optimal diagnostic value therefore, the cut-off should not be too low. It would therefore seem sensible to keep in line with VRL and adopt an ELISA cut-off control equivalent to 10 RIA units.

A good clinical history is essential however and $\vec{\bullet}$ must be taken into account when a low positive of an equivocal result is obtained. Such a result woul imply that HAV was implicated in an episode hepatitis occurring several months previously. A low positive result may also occur if the specimen was taken in the prodromal stage of hepatitis A, or more rarely, during the first few days of icterus. A second specimen should then clarify the situation.

\section{Conclusion}

This trial demonstrates that the DMRQC-Organon ELISA and the unmodified Organon Tecknika $\overline{-}$ ELISA for hepatitis A IgM perform well. They are specific and sensitive, without being too sensitive, $\delta$ and discriminate well between acute and late convalescent sera. However the hybrid test does have the 의 advantage of slightly better colour development $>$ making it an easier test to read by eye.

We are most grateful to Organon Tecknika for the supply of their reagents and their exceedingly ${ }_{0}$ friendly co-operation.

\section{Appendix}

Test procedure (as issued to the participating $\stackrel{\oplus}{+}$ laboratories)

Samples to be tested should be diluted initially to음

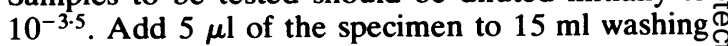


buffer (PBS-Tween) and mix well without frothing using a vortex mixer if available. Positive and negative controls (which are supplied predilited to $10^{-2 \cdot 5}$ ) should be diluted $1 / 10$.

1 Aspirate storage buffer from wells and add $90 \mu \mathrm{l}$ buffer to each well.

2 Add $10 \mu$ l volumes of diluted specimens to wells reserving six wells for control specimens ( 4 positive and 2 negative). Add $10 \mu$ l volumes of the diluted control samples to appropriate wells.

3 Seal plate and incubate for 4 hours at $37^{\circ} \mathrm{C}$ in a humid incubator.

4 Wash wells 4 times with washing buffer.

5 Dilute HAV antigen 1/5 in washing buffer and add $100 \mu$ l to each well. Only make up the minimum amount of antigen necessary.

6 Seal plate and incubate overnight $\left(16^{-}-20 \mathrm{~h}\right)$ at room temperature $\left(15-25^{\circ} \mathrm{C}\right)$ in a humid container.

7 Wash wells four times with washing buffer.

8 Add $100 \mu$ l conjugate* to each well.

9 Seal plate and incubate for $60 \mathrm{~min}$ in a humid incubator at $37^{\circ} \mathrm{C}$.

10 Wash wells four times with washing buffer.

11 Add $100 \mu$ l substrate** to each well and incubate in the dark for $45 \mathrm{~min}$ at room temperature $\left(20-25^{\circ} \mathrm{C}\right)$.

12 Stop the reaction by adding $100 \mu$ sulphuric acid $(2 \mathrm{~mol} / \mathrm{l})$ to each well.

13 Read results.

* The conjugate should be re-suspended $10 \mathrm{~min}$ before use. Add $1.4 \mathrm{ml}$ washing buffer to each ampoule and pool contents of ampoules if more than one is needed. Seven ampoules should be just sufficient for one plate.

** The substrate solution should be made up just before the last washing procedure. Add one OPD tablet to $10 \mathrm{ml}$ distilled water in a pre-rinsed glass bottle and allow to dissolve completely in the dark (allow $10 \mathrm{~min}$ ). Dissolve one urea peroxide tablet in $7.5 \mathrm{ml}$ distilled water. Immediately before use, add $200 \mu \mathrm{l}$ urea peroxide solution to $10 \mathrm{ml}$ OPD solution. Keep this substrate solution in the dark.

\section{Notes on reading the results}

If an Organon Tecknika Microelisa reader or Titertek Multiskan is available, zero the reader without a plate inside then read the test plate using the $492 \mathrm{~nm}$ filter. The negative control must give an extinction of less than $0 \cdot 20$, the positive control must give an extinction above $\mathbf{0 . 4 5}$. (If controls do not behave as expected, the results of the specimens under test are invalid and the test must be repeated.) Samples are deemed positive when their extinction is higher than $0 \cdot 20$. For reading by eye, the negative control must give a (almost) colourless result; the positive control must give a clear yellow-orange col- our. Specimens giving a colour clearly greater than the negative control are positive.

When reporting results we would ask laboratories to send extinction readings for all test specimens if tests have been read spectrophotometrically, as well as readings by eye:

+ positive-good colour development.

\pm weakly positive-more colour development than in negative control.

- negative-colourless, or almost.

\section{References}

' Frosner GG, Deinhardt F, Scheid R, Gauss-Muller V, Holmes N, Messelberger V, Siegl G, Alexander JJ. Propagation of human hepatitis A virus in hepatoma cell line. Infection 1979;7:3036.

${ }^{2}$ Provost PJ, Hilleman MR. Propagation of human hepatitis A virus in cell culture in vitro. Proc Soc Exp Biol Med 1979;160:213-21.

${ }^{3}$ Flehmig B. Hepatitis A-virus in cell culture: I. Propagation of different hepatitis A-virus isolates in a fetal rhesus monkey kidney cell line (FrhK-4). Med Microbiol Immunol 1980;168:239-48.

4 Feinstone SM, Kapikian AZ, Purcell RH. Hepatitis A: detection by immune electron microscopy of a virus-like antigen associated with acute illness. Science 1973;182:1026-8.

${ }^{5}$ Deinhardt F, Holmes AW, Capps RB, Popper H. Studies on the transmission of human viral hepatitis to marmoset monkeys. $i$. Transmission of disease, serial passages, and description of liver lesions. J Exp Med 1967;125:673-88.

- Holmes AW, Wolfe L, Deinhardt F, Conrad ME. Transmission of human hepatitis to marmosets: further coded studies. $J$ Infect Dis 1971;124:520-1.

' Provost PJ, Ittensohn OL, Villarejos VM, Hilleman MR. A specific complement fixation test for human hepatitis A employing CR 326 virus antigen. Diagnosis and epidemiology. Proc Soc Exp Biol Med 1975;148:962-9.

- Miller WJ, Provost PJ, McAleer WJ, Ittensohn OL, Villarejos VM, Hilleman MR. Specific immune adherence assay for human hepatitis A antibody. Application to diagnostic and epidemiologic investigation. Proc ${ }^{-S o c}$ Exp Biol Med 1975;149:254-61.

9 Purcell RH, Wong DC, Moritsugu Y, Dienstag JL, Routenberg JA, Boggs JD. A microtiter solid phase radioimmunoassay for hepatitis $A$ antigen and antibody. $J$ Immunol 1976;116:34956.

${ }^{10}$ Duermeyer W, Van der Veen J. Specific detection of IgMantibodies by ELISA, applied in hepatitis A. Lancet $1978 ; i \mathbf{i}: 684-5$ and 906.

"Flehmig B, Ranke M, Berthold H, Gerth HJ. Solid phase radioimmunoassay for detection of IgM antibodies to hepatitis A virus. $J$ Infect Dis 1979;140:169-75.

12 Locarnini SA, Ferris AA, Lehmann NI, Gust ID. The antibody response following hepatitis $\mathrm{A}$ infection. Intervirology 1977;8:309-18.

${ }^{13}$ Parry JV. Hepatitis A infection: Guidelines for development of satisfactory assays for laboratory diagnosis. Med Lab Sci 1981;38:303-11.

14 Parry JV. In vitro propagation of hepatitis A virus and its application to laboratory diagnosis. In: Proceedings of Second International Hepatitis Workshop, Stirling, 1982, 15-23 Edinburgh Nuclear Enterprises Ltd, 1983.

Requests for reprints to: Dr PS Gardner, Director, Division of Microbiological Reagents and Quality Control, 175 Colindale Avenue, London NW9 5HT, England. 